\title{
Fish Biodiversity Assemblages and Fishing Gears Used at Chinadi Beel in Narsingdi District of Bangladesh
}

\author{
Bhaskar Chandra Majumdar ${ }^{1,2 *}$, Sulav Indra Paul ${ }^{3}$, Mahmudul Hasan ${ }^{4}$, Tamina Kabir ${ }^{5}$, \\ Mahibul Islam ${ }^{4}$ and Ilias Ebne Kabir ${ }^{1,6}$
}

\begin{abstract}
${ }^{1}$ Department of Fisheries Technology, Bangabandhu Sheikh Mujibur Rahman Agricultural University, Gazipur- 1706, Bangladesh ${ }^{2}$ BIBIYA Dairy, Agro and Food Ltd., Nikunja-2, Khilkhet, Dhaka-1229, Bangladesh

${ }^{3}$ Institute of Biotechnology and Genetic Engineering, Bangabandhu Sheikh Mujibur Rahman Agricultural University, Gazipur-1706, Bangladesh

${ }^{4}$ Department of Marine Sciences, University of Gothenburg, Gothenburg, Sweden

${ }^{5}$ Department of Biological and Environmental Sciences, University of Gothenburg, Gothenburg, Sweden

${ }^{6}$ WorldFish, Bangladesh and South Asia Office, Banani, Dhaka-1213, Bangladesh
\end{abstract}

*Corresponding author: bhaskar.bsmrau@gmail.com (ORCID ID: 0000-0001-6607-0827)

Paper No. 862

Received: $19-08-2020$

Revised: 23-11-2020

Accepted: 09-12-2020

\begin{abstract}
The present survey disclosed the available fish biodiversity and the gears used for fishing in the Chinadi beel, Narsingdi, Bangladesh, for a certain period. Data was collected through face to face conversations using a well-structured questionnaire and cross-checked. About 51 species of fish under 7 orders and 19 families were found. The dominant order was found jointly for Cypriniformes (29.41\%) and Siluriformes (29.41\%). About 39 least concern (75\%), 5 vulnerable $(9.62 \%), 6$ near threatened $(11.54 \%)$, and 1 not evaluated (1.92\%) species were observed. Fifteen different types of fishing gears (8 major categories) are used for fishing by the fishermen, of which seine net was the most leading gear. Most of the gears are banned for a period due to its unauthorized mesh size. The price of fishing gears was ranged from 2501,00,000 Tk, of which the highest price was for seine net. The uppermost catch per unit effort (CPUE) was found for ber jal that was $15-18 \mathrm{~kg} /$ day. Most of the fishing gear was operated throughout the year, but limited in the dry season. However, the variety of fish abundance and species diversity is declining day by day in this beel. To protect the fish diversity of the Chinadi beel, it is recommended to establish effective fishery management practices, monitoring overfishing, and awareness of fishermen is highly recommended.
\end{abstract}

\section{Highlights}

(0 The beel has a rich fish biodiversity and important for fisheries resources in the middle-east part of Bangladesh. About 51 species of fish under 7 orders and 19 families were found. Fifteen fishing gears (8 major categories) are used for fishing by the fishermen.

o Now-a-days, biodiversity of fish was decreased due to over fishing, water pollution, heavy siltation, rapid urbanization and intervention of human.

Keywords: Fish biodiversity, Gears, Fishermen, Chinadi beel

Bangladesh is a riverine country immensely gifted with many inland water resources like rivers, beels, haors, baors, floodplains, canals, and many humanmade lakes. Bangladesh's inland water bodies are enriched with 265 species of freshwater finfishes approximately (Hemal et al. 2017; Rahman
2005). In Bangladesh, there is a proverb- "rice and fish makes the Bengali people" that highlight

How to cite this article: Majumdar, B.C., Paul, S.I., Hasan, M., Kabir, T., Islam, M. and Kabir, I.E. 2020. Fish Biodiversity Assemblages and Fishing Gears Used at Chinadi Beel in Narsingdi District of Bangladesh. IJAEB, 13(4): 403-413.

Source of Support: None; Conflict of Interest: None 
the importance of fish food. Moreover, fish alone contribute more than $63 \%$ of animal protein, as well as diverse essential vitamins and minerals in this community (Majumdar and Rashid 2017; Majumdar et al. 2016; Shovon et al. 2017). Over the last decades, ecosystems of water bodies have deteriorated from intense anthropogenic activities resulting in loss of habitat and destruction and so, huge quantity of fish fauna have become remarkably endangered in all types of freshwater bodies. Freshwater fishes of all types of waterbodies are one the most threatened taxonomic groups due to extreme sensitivity to the qualitative and quantitative variation of aquatic habits (Darwall and Vié 2005). Up to the present moment, around 54 fish species from freshwater have been marked as threatened species in Bangladesh by IUCN (2020). Due to extreme change in freshwater ecology and massive destruction of natural habitats most of the wild fish species have seriously declining day by day in Bangladesh (Hossain et al. 2012). All these findings undoubtedly imply the necessity of water body specific biodiversity studies which is prerequisite to evaluate the current status for the implication of sustainable management to safe the fisheries resources (Imteazzaman and Galib 2013). However, limited number of research conducted on biodiversity status of different water bodies in this country (Ahmed et al. 2004; Galib et al. 2009; Hossain et al. 2009; Hossain et al. 2012; Imteazzaman and Galib 2013; Mohsin and Haque 2009; Mohsin et al. 2009; Rahman et al. 2012; Saha and Hossain 2002; Shahjahan et al. 2001; Sheikh et al. 2018; Zafar et al. 2007).

Besides the major flood plains of the river Padma, Meghna and Jamuna, there are thousands of large and small sizes beels present in Bangladesh. Among them, Chinadi beel is located in Dulalpur union, eight kilometers west of Shibpur Upazila in Narsingdi district of Dhaka division $\left(24^{\circ} 03^{\prime} 40.2^{\prime \prime} \mathrm{N}\right.$ latitudes and $90^{\circ} 40^{\prime} 07.2^{\prime \prime} \mathrm{E}$ longitudes) and 550 bighas $(16,500$ decimals) in size. The beel is significantly well-known in Narsingdi district of Bangladesh for its natural sceneries, fish production and also as a source of income for local fisherman. A large number of fisherman families are completely depending on the Chinadi beel resources and they use various types of fishing crafts and gears for marketable utilization of the Chinadi beel fishery assets. However, there is no record found on the fish fauna diversity status of the Chinadi beel. Therefore, the aim of this investigation is to provide information on the present fish fauna biodiversity status and the fishing gears used by the fishermen for fishing in the beel.

\section{MATERIALS AND METHODS}

\section{Study area and duration}

The existing study was performed in the Chinadi beel located at Shibpur upazila of Narsingdi district connected to Shitalakshya river (Fig. 1). The geographical location of the experimental area is $24^{\circ} 03^{\prime} 40.2^{\prime \prime} \mathrm{N}$ latitudes and $90^{\circ} 40^{\prime} 07.2^{\prime \prime} \mathrm{E}$ longitudes. The investigation was conducted for a time of 12 months from July to June. Data was collected personally through face to face interviews using well-structured questionnaire and cross-check (Fig. 2).

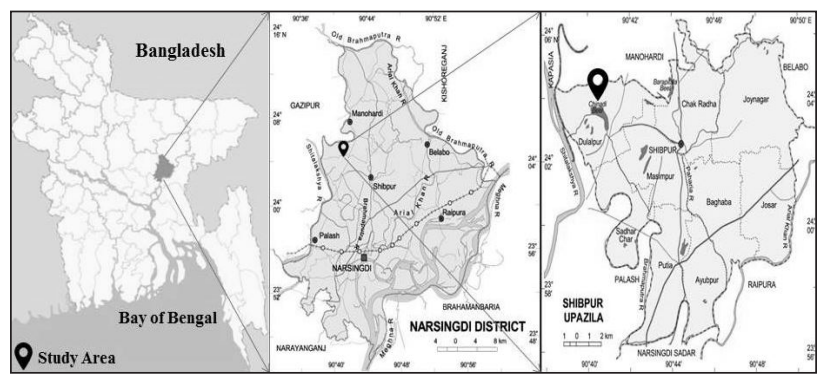

Fig. 1: Geographical location of the study area

\section{Collection of primary data}

A well-structured questionnaire with two parts namely fish diversity and fishing gears used for fishing was designed and data were collected through face to face interview with local fishermen. Sampling method (simple random) with questionnaire interviews was surveyed with 110 fishermen in the Chinadi beel area to collect the data. The interview with fishermen was completed at their residence and/or beel spots during fishing.

\section{Study on fishing gears}

Fishing gears operated at Chinadi beel by fishermen were studied by direct physical observation. A measuring scale was used as a tool to measure mesh size of existing fishing gears. Direct observation was conducted to record data on fishing gear like shape and mesh size $(\mathrm{cm})$ of fishing gears. Information 
about the price of fishing gear, species catch by individual gear, catch per unit effort (CPUE)/day and operation period of individual fishing gear were collected through interviewing with fishermen.

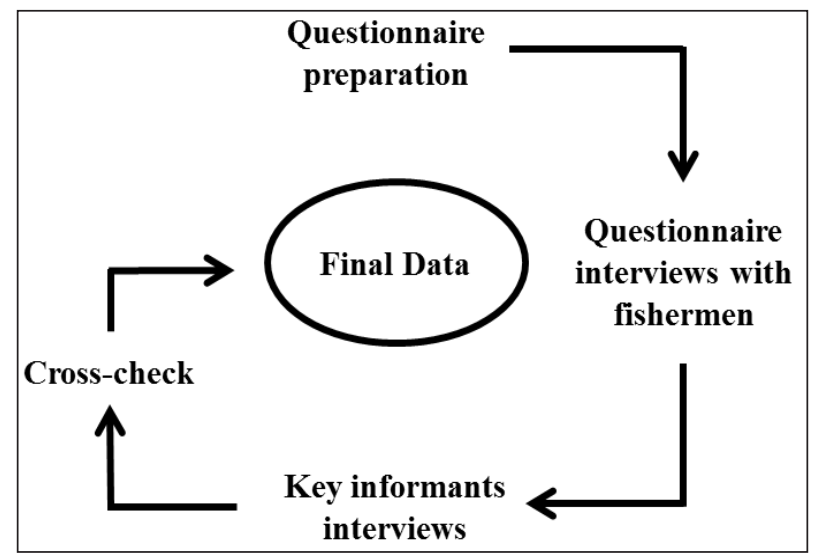

Fig. 2: Data collection methods from fishermen and finalization after cross-check

\section{Fish biodiversity study}

Freshly caught unsorted samples of different gears were collected and then sorted species wise with the help of fisher's. Local name of each individual freshly samples were recorded from the fishermen.

\section{Secondary data}

After regular field study, the primary data were compared with the available secondary data to make a precise and composite picture of the present study area. Books, journals, Upazila Fisheries Officer (UFO) etc. were used to modify, cross-check and accurate the information. The collected gears were assorted under various major classes followed by Ahmed (1971). Fish samples captured by different gears were identified and then taxonomically characteristics followed by Talwar and Jhingran (1991) and Rahman (2000). Scientific name and English name were studied with the help of Froese and Pauly (2016).

\section{Data processing and analysis}

All the data were accumulated to analyze the findings. Tabular technique was applied by using simple statistical tools such as percentages and averages. For processing and analyzing the data "Microsoft Excel-2013" was used. After processing and calculating the data carefully, the most agreeable data was written to a final sheet from which is classified to reveal the results of the investigation. As a final point, based on the data type, it was illustrated in textual, tabular and graphical format to make the present findings easily understandable.

\section{RESULTS AND DISCUSSION}

The Chinadi beel is a beel close to the Shitalakshya River where water level of the beel varying from different months that is ranged within minimum $1 \mathrm{ft}$ to maximum $10 \mathrm{ft}$ in depth. The maximum depth of water was noted during September where the beel became dry in winter season (February to April). In Bangladesh, about 260 freshwater fish species were recorded belonging to 55 families (Majumdar 2017; Rahman 1998). In compliance with the statement of the local fishermen as well as other people of that area, about 15 years ago this beel was abundant with various types of freshwater fishes but now the diversity of fish fauna is decreasing day by day.

\section{Fish Biodiversity}

In this study depicts existence of total 51 species in 19 families under 7 orders (Table 1). Both Cypriniformes (29.41\%) and Siluriformes (29.41\%) found as dominant order followed by Perciformes (27.45\%), Synbranchiformes (5.88\%), Osteoglossiformes (3.92\%), Clupeiformes (1.96\%) and Cyprinodontiformes (1.92\%). Fishes of Clupeiformes and Cyprinodontiformes orders were rarely found in the study area (Fig. 3).

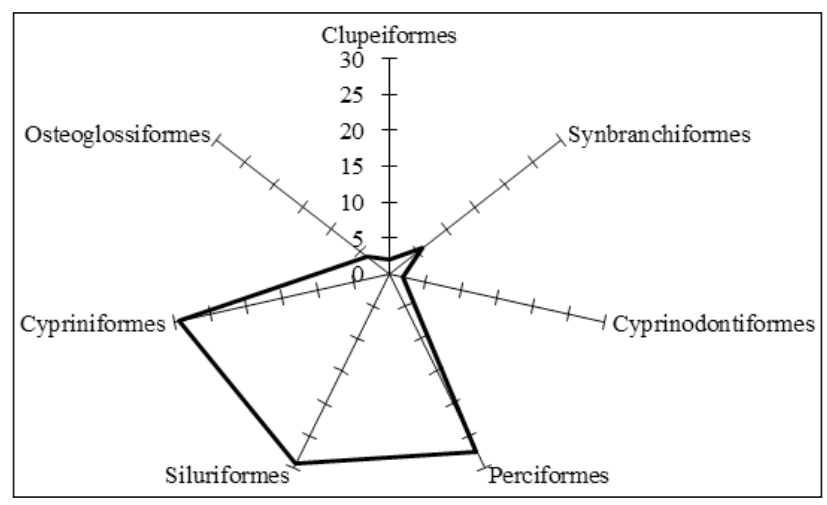

Fig. 3: Fish species percentage on the basis of order in the Chinadi beel

In previous, there has not been studied about Chinadi beel and so far. But it was reported that a total 47 fish species were found in BSKB beel (Rahman 2000) and total of 40 species of fish in Chanda beel (Ehshan et al. 2000) which was less than 
Table 1: Systematic position of fish species with their local name, english name and scientific name, and IUCN conservation fish status in Chinadi Beel at Narsingdi district, Bangladesh

\begin{tabular}{|c|c|c|c|c|c|c|}
\hline \multirow[t]{2}{*}{ Order } & \multirow[t]{2}{*}{ Family } & \multirow[t]{2}{*}{ Local name } & \multirow[t]{2}{*}{ English name } & \multirow[t]{2}{*}{ Species } & \multicolumn{2}{|c|}{$\begin{array}{l}\text { IUCN conservation } \\
\text { status }\end{array}$} \\
\hline & & & & & GL & BD \\
\hline \multirow[t]{15}{*}{ Cypriniformes } & \multirow[t]{15}{*}{ Cyprinidae } & Katol & Catla & Gibelion catla & $\mathrm{LC}$ & LC \\
\hline & & Silver carp & Silver carp & $\begin{array}{l}\text { Hypophthalmichthys } \\
\text { molitrix }\end{array}$ & NT & NA \\
\hline & & Bighead carp & Bighead carp & $\begin{array}{l}\text { Hypophthalmichthys } \\
\text { nobilis }\end{array}$ & $\mathrm{DD}$ & NA \\
\hline & & Ruhu & Ruhu carp & Labeo rohita & LC & LC \\
\hline & & Mrigal & Mrigal & Cirrhinus cirrhosus & LC & NT \\
\hline & & Grass carp & Grass carp & Ctenopharyngodon idella & LC & NA \\
\hline & & Common carp & Common carp & Cyprinus carpio & VU & NA \\
\hline & & Mola & Mola carplet & Amblypharyngodon mola & $\mathrm{LC}$ & $\mathrm{LC}$ \\
\hline & & Darkina & Flying barb & Esomus danricus & $\mathrm{LC}$ & $\mathrm{LC}$ \\
\hline & & Bata & Bata labeo & Labeo bata & $\mathrm{LC}$ & $\mathrm{LC}$ \\
\hline & & Kalibaus & Orange fin labeo & Labeo calbasu & $\mathrm{LC}$ & $\mathrm{LC}$ \\
\hline & & Gonia & Kuria labeo & Labeo gonius & LC & NT \\
\hline & & Tit punti & Ticto barb & Pethia ticto & $\mathrm{LC}$ & VU \\
\hline & & Teriputi & Onespot barb & Puntius terio & $\mathrm{LC}$ & LC \\
\hline & & Rajputi & Java barb & Barbonymus gonionotus & $\mathrm{LC}$ & NA \\
\hline Cyprinodontiformes & Aplocheilidae & Kanpona & Blue panchax & Aplocheilus panchax & $\mathrm{LC}$ & $\mathrm{LC}$ \\
\hline \multirow[t]{15}{*}{ Siluriformes } & Clariidae & Magur & Air breathing catfish & Clarias batrachus & LC & LC \\
\hline & \multicolumn{2}{|c|}{ Heteropneustidae Shing } & Stringing catfish & Heteropneustes fossilis & $\mathrm{LC}$ & LC \\
\hline & Pangasiidae & Pangas & Yellow tail catfish & Pangasius pangasius & LC & EN \\
\hline & \multirow[t]{4}{*}{ Siluridae } & Boal & Freshwater shark & Wallogo attu & VU & VU \\
\hline & & Kani Pabda & Pabo catfish & Ompok bimaculatus & NT & $\mathrm{EN}$ \\
\hline & & Pabda & Pabda catfish & Ompok pabda & NT & EN \\
\hline & & Baghair & Dwarf goonch & Bagarius bagarius & NT & CR \\
\hline & \multirow[t]{2}{*}{ Schilbeidae } & Baspata & Jamuna aila & Ailia coila & NT & $\mathrm{LC}$ \\
\hline & & Garua & Garua bachua & Clupisoma garua & $\mathrm{LC}$ & EN \\
\hline & \multirow[t]{6}{*}{ Bagridae } & Rita maach & Rita & Rita rita & $\mathrm{LC}$ & EN \\
\hline & & Tengra & Striped river catfish & Mystus vittatus & $\mathrm{LC}$ & $\mathrm{LC}$ \\
\hline & & Gulsha tengra & Tengra mystus & Mystus tengra & $\mathrm{LC}$ & $\mathrm{LC}$ \\
\hline & & Aor & Long-whiskered catfish & Sperata aor & $\mathrm{LC}$ & VU \\
\hline & & Gang tenga & Gangetic tengra & Mystus cavasius & $\mathrm{LC}$ & NT \\
\hline & & Guizza aor & Giant river-catfish & Sperata seenghala & $\mathrm{LC}$ & VU \\
\hline \multirow[t]{14}{*}{ Perciformes } & \multirow[t]{2}{*}{ Ambessdae } & Ranga chanda & Indian glassy fish & Chanda ranga & LC & NA \\
\hline & & Nama chanda & Elongate glass perchlet & Chanda nama & $\mathrm{LC}$ & LC \\
\hline & Anabantidae & Koi & Climbing perch & Anabas testudineus & $\mathrm{LC}$ & $\mathrm{LC}$ \\
\hline & Belontiidae & Kholisha & Striped gourami & Trichogaster fasciata & $\mathrm{LC}$ & $\mathrm{LC}$ \\
\hline & \multirow[t]{4}{*}{ Channidae } & Gozar & Great snakehead & Channa marulius & $\mathrm{LC}$ & EN \\
\hline & & Shol & Snakehead murrel & Channa striata & LC & LC \\
\hline & & Gachua & Walking snakehead & Channa orientalis & VU & $\mathrm{LC}$ \\
\hline & & Taki & Spotted snakehead & Channa punctata & $\mathrm{LC}$ & $\mathrm{LC}$ \\
\hline & \multirow[t]{2}{*}{ Cichlidae } & Tilapia & Mozambique tilapia & Oreochromis mossambicus & VU & NA \\
\hline & & Nilotica & Nile tilapia & Oreochromis niloticus & $\mathrm{LC}$ & NA \\
\hline & Gobiidae & Bele & Tank goby & Glossogobius giuris & $\mathrm{LC}$ & $\mathrm{LC}$ \\
\hline & \multirow[t]{2}{*}{ Nandidae } & Napit koi & Badis & Badis badis & $\mathrm{LC}$ & NT \\
\hline & & Meni & Gangetic leaffish & Nandus nandus & $\mathrm{LC}$ & NT \\
\hline & Osphronemidae & Kholisha & Banded gourami & Colisa fasciata & $\mathrm{LC}$ & $\mathrm{LC}$ \\
\hline
\end{tabular}


Fish diversity and gears used in Chinadi beel

\begin{tabular}{|c|c|c|c|c|c|c|}
\hline \multirow[t]{2}{*}{ Clupeiformes } & Clupeidae & Chapila & $\begin{array}{l}\text { Ganges River Gizzard } \\
\text { Shad }\end{array}$ & Gonialosa manmina & LC & LC \\
\hline & & Kachki & Ganges river sprat & Corica soborna & LC & LC \\
\hline \multirow[t]{2}{*}{ Osteoglossiformes } & Notoptetidae & Chital & Humped featherback & Chitala chitala & NT & EN \\
\hline & & Foli & Grey featherback & Notopterus notopterus & LC & VU \\
\hline \multirow[t]{3}{*}{ Synbranchiformes } & Mastacembelidae & Tara baim & Striped spiny eel & Macrognathus aculeatus & NE & NT \\
\hline & & Sal baim & Tire track eel & Mastacembelus armatus & LC & EN \\
\hline & & Kuchia & Cuchia & Monopterus cuchia & VU & VU \\
\hline
\end{tabular}

${ }^{*} G L=$ Global; $B D=$ Bangladesh $L C=$ Least concern; $E N=$ Endangered $V U=$ Vulnerable; $N T=$ Near threatened $N E=$ Not evaluated; $N A=$ Not available; $D D=$ Data deficient $; C R=$ Critically endangered .

our study. Chakraborty and Mirza (2007) found 70 fish species from the Gharia beel. Halim et al. (2017) noted that in Kafrikhal beel about 54 species of the fish fauna were reported. It is revealed in another study that 68 fish species were recorded in water bodies of Itna, Kishoregonj (Sakawat 2002).

Haroon et al. (2002) recorded 92 of species finfish as well as prawns from Sylhet-Mymensingh sub basins. Mohsin et al. (2014) described approximately 53 fish species (under 10 orders, 28 families and 47 genera) identified and collected from the Andharmanik River of Patuakhali district in where Perciformes (18 species) was found as the dominant order of fishes followed by Siluriformes (12 species) as well as Clupeiformes (9 species). Hossain et al. (2009) and Ahmed et al. (2004) identified about 114 fish species (under 29 families) and 52 fish species from Chalan beel (Natore-Pabna-Sirajganj) and Shakla beel (Brahmanbaria), respectively. Kostori et al. (2011) investigated that 82 small indigenous species (SIS) were contained in 22 families, 10 orders and 46 genera and that the dominant order Cypriniformes (42.68\%) comprises 35 species which is parallel to our study.

In the Chinadi beel, about 39 least concern (75\%), 5 vulnerable $(9.62 \%), 6$ near threatened $(11.54 \%)$ and 1 not evaluated (1.92\%) species were observed according to the IUCN conservation status of global (IUCN 2015) during the study period (Fig. 4; Table 1). It was remarkable that there was no species found during the study which were globally endangered by the IUCN conservation status (IUCN 2015). According to the IUCN conservation status of Bangladesh (IUCN 2015), about 23 least concern $(44.23 \%), 8$ endangered $(15.38 \%), 5$ vulnerable $(11.54 \%), 6$ near threatened (11.54\%), 8 not available $(15.38 \%)$ and 1 critically endangered (1.92\%) species were observed throughout the study time (Fig. 4; Table 1). Because of over exploitation of fisheries assets in the beel, these species are also decreasing day by day. Fish biodiversity are declining day by day because of rapid urbanization, over fishing, unawareness of fishermen, use of destructive fishing gear, etc.

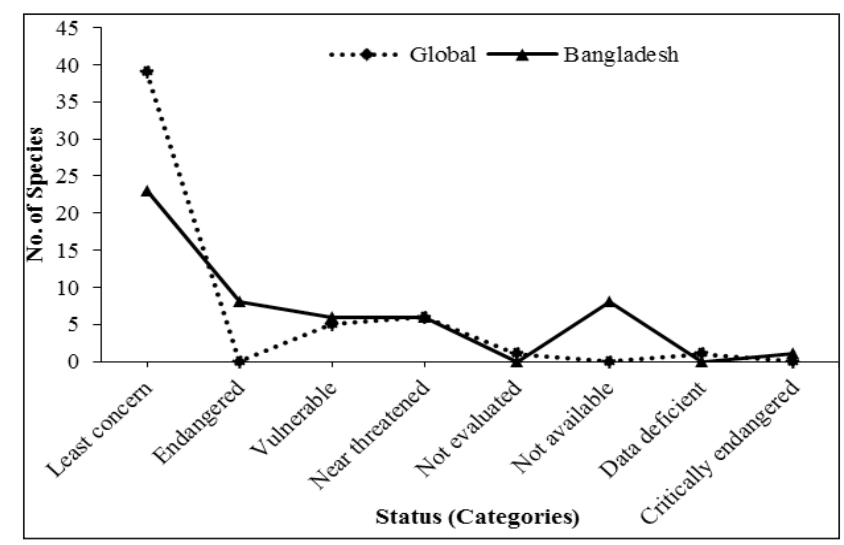

Fig. 4: IUCN conservational status (\%) of available fish species in the Chinadi beel

About 44 non-resident species fish and resident species identified from Pirla beel under Netrokona district in which 30 were common, 9 rare and 5 highly endangered (Siddique 2001). Ahsan (2008) identified 105 fish species from Chalan beel where 6 species were found as critically endangered, 14 vulnerable, 25 endangered, and 45 threatened. Halim et al. (2017) recorded a total of 54 fish species from the Kafrikhal beel including 10 endangered and 7 critically endangered. Mohsin et al. (2014) observed 5 vulnerable, 3 endangered, and 2 critically endangered species in their study area. In here, Galib et al. (2013) documented 6 critically endangered, 10 endangered and 10 vulnerable fish species from the Jamuna. Rahman et al. (2015) detailed 2 critically endangered, 7 endangered and 7 vulnerable fish species from Rabnabad channel that was similar to our results. Small indigenous fishes (SIS) were also abundant in the different wetlands such as rivers, ponds, canals, beels, jheels, streams, 
etc. in Bangladesh at a certain time in the past (Ahsan 2008; IUCN 2020; Rahman 2005). But now-adays, these SIS species are going to be disappeared despite of their limited ability to reproduce naturally due to environmental degradation as well as habitat degradation. Destruction of fish habitat by establishment of high roads, drainage, embankments and over exploration with destructive fishing gear, have been marked as causes to destroy our fishery resources (Ali 1997; IUCN 2020).

According to IUCN (2015), 18 threatened fishes were found in the Chalan beel in which 8 vulnerable (12\%), 8 endangered (12\%) and 2 critically endangered (3\%). Joadder et al. (2015) revealed that $72 \%$ of the total fish species were listed as least concern based on the IUCN Global conservation status. Among the identified fishes, there is no species found under threatened condition based on the Global conservation aspects. Whereas, those fishes were recorded as threatened fishes in Bangladesh, occupying either least concern or near threatened in the Global aspects. For example, in Bangladesh Chitala chitala and Ompok pabda were considered endangered but globally it was categorized as near threatened species. The objective of IUCN red list is to help the international community to follow up the species availability and also helps to control species extinction by suggesting the significance of conservation issues to the public as well as policy makers (Alam et al. 2013).

\section{Fishing gears}

The fishery of the Chinadi beel is multispecies and multigear in nature. Fishermen use numerous types of fishing gears for fishing based on seasons and water depth of the beel. Variation in net types, lengths as well as mesh sizes of the net varying based on the fishermen choice, economic conditions of the persons involved in fishing practices and also the abundance of fish.

A total of eight (8) types of gears were found during the survey used by the fishers. Categorization of different fishing gear with their shape, mesh size, major species caught, price, catch per unit effort (CPUE) and operation period in the beel are showed in Table 2. About 15 various types of fishing gear were classified under 8 major classes and these were gill net (current jal, chandi jal, sutar jal), seine net (ber jal, indian net jal), lift net (dharma jal, khora jal), push net (thela jal, moia jal), cast net (jhaki jal traps (pangus chai, anta, chhara barshi), hook and line (chingri barshi) and wounding gear (koach) (Table 2). In Chinadi beel, the fishermen used different types of fishing gear (Fig. 5). Based on the usage, the seine net was found as the most usable gear by the fishermen constituting $35.45 \%$ followed by gill net $(23.64 \%)$ among total gear type.

The fishermen also used lift net (11.82\%), push net $(6.36 \%)$, cast net $(10.91 \%)$, traps $(4.55 \%)$, hooks and line $(4.55 \%)$ and wounding gear $(2.73 \%)$. The result stated that the seine net was highly preferable gear by the fishermen. In Fig. 6, it was demonstrated that the maximum number of fish species was caught by using seine net followed by gill net, lift net, cast net, push net, traps, hooks and line and wounding gear. In Table 2, different shapes fishing gear used during fishing with their respective mesh size, major species caught, price, CPUE as well as operating period at Chinadi Beel, where a total of eight (8) types of gears were noticed to be used by the fishermen during fishing in the beel. There was no previous study of gears in Chinadi beel was established and thus it was impossible to compare our findings with previous one. Major categories of gears include nets, traps and hooks.

Netting, spearing, trapping, angling, and fishing are the mostly used fishing techniques maintained Bangladesh (Dewan and Mazid 1994). Adjacent to many researcher such as Alam et al. (2009); Alam et al. (1997); Aosomboon (1994); Chakrabarty et al. (1959); Das et al. (2003); Dewan and Mazid (1994); Khaled (1985); Rahman et al. (1993), studied on the different fishing techniques performed in beels and riveres during fishing. However, Flowra et al. (2011) and Rahman et al. (2015) who acknowledged 16 different gears under 7 categorizes that supported the present findings. Nonetheless Rahman et al. (2016) and Jaman et al. (2019) found total seven and eighteen major types of fishing gears defined in the Payra River, respectively. Rahman et al. (2017) also revealed 19 distinct types of gear under 9 major classes in Agunmukha River. Furthermore, Miah et al. (2010) recorded about six types of fishing nets from Shitalakshya River. Siddiq et al. (2013) conducted a study on Dogger beel and mentioned 5 types of fishing nets (ber jal, jakhi jal, current jal, dharma jal, and thela jal), 3 fishing traps (unta chai, bitte chai and icha chai), 2 hooks (chara borshi and 
Table 2: Different fishing gear with their mesh size, shape, price, and major species caught, CPUE and operating period in Chinadi Beel at Narsingdi district, Bangladesh

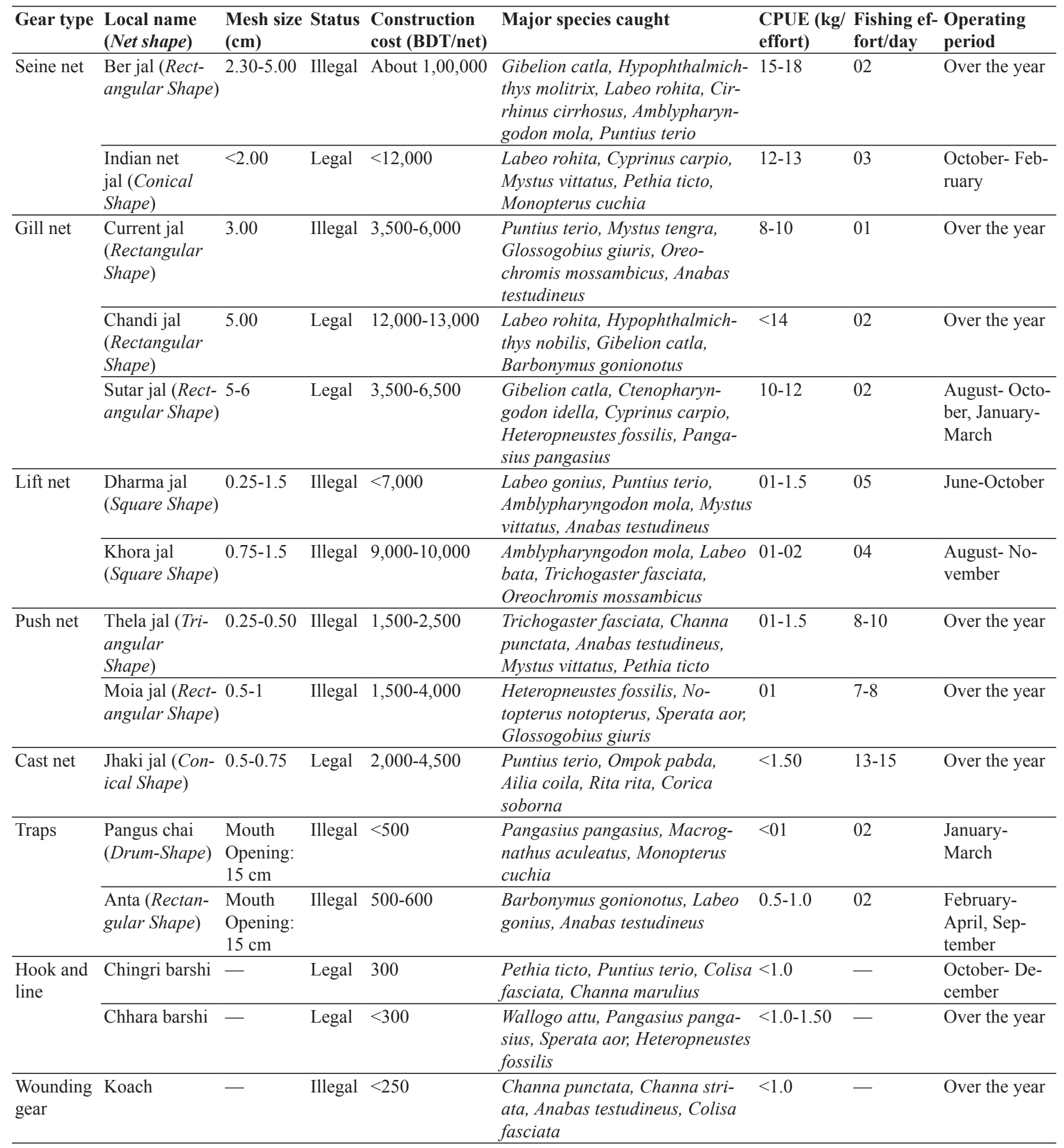

*Jal= Fishing net; BDT= Bangladeshi Taka (currency); CPUE= Catch Per Unit Effort.

chip borshi) and 2 spears (teta with hooks teta and without hooks).

In Table 2, fishing gears of different shapes such as rectangular shape (ber jal, current jal, chandi jal, sutar jal, moia jal, anta), conical shape (Indian net jal, jhaki jal), square shape (dharma jal, khora jal), triangular shape (thela jal) and drum-shape (pangas chai). The mesh size was ranged from 0.25 to 6.00 , found in 5 types fishing gear (net) in these study (Table 2). Due to destructive nature of some fishing gear, most 
of the gears were banned (illegal) by departmental authority to save the fish diversity. Only Indian net jal, chandi jal, sutar jal, jhaki jal, chingri barshi and chhara barshi were announced as legal gear by the authority. In the present study, the price of fishing gears were ranged from 250-1,00,000 Tk (Table 2). The highest price was observed in case of seine net (ber jal: about 1,00,000 Tk) followed by chandi jal $(12,000-13,000 \mathrm{Tk})$, Indian net jal (<12,000 Tk), khora jal (9,000-10,000 Tk), dharma jal $(<7,000 \mathrm{Tk})$, sutar jal (3,500-6,500 Tk), current jal (3,500-6,000 Tk), jhaki jal (2,000-4,500 Tk), moia jal (1,500-4,000 Tk), thela jal (1,500-2,500 Tk), anta (500-600 Tk), pangus chai $(<500 \mathrm{Tk})$, chingri barshi (300 Tk), chhara barshi $(<300$ $\mathrm{Tk})$ and the lowest price was for koach $(<250 \mathrm{Tk})$ (Table 2). This investigation recorded that maximum amount of species caught by seine net (ber jal, Indian net jal) and few amount by wounding gear.

The maximum CPUE was recorded for ber jal 15-18 $\mathrm{kg} /$ day where the CPUE of chandi jal, Indian net jal, sutar jal, current jal, khora jal, dharma jal, thela jal, jhaki jal and moia jal was found <14, 12-13, 10-12, 8-10, $1-2,01-1.5,01-1.5,<1.50$, and $1 \mathrm{~kg} /$ day, respectively which was fewer than seine net and greater than any other gear (traps, hooks and line, wounding gears) used in the Chinadi beel. Maximum fishing efforts per day were correlated with the highest catch composition of any fishing gear. Table 2 represents the highest fishing effort done by those fishing gears which are easy to handle and require less fishermen such as jhaki jal, thela jal, moia jal, dharma jal and khora jal. The fishermen percentage (Fig. 5) and number of species caught (Fig. 6) in the Chinadi beel using different types of fishing gear. Seine net is the highly preferable and effective fishing gear in the beel area. From Ramnabad River, Ali et al. (2015) noticed the maximum utilization of seine net $(60 \%)$ and gill net (20\%), additionally the lesser utilization were found in lift net $(0.6 \%)$, cast net $(1.2 \%)$, push net $(1.8 \%)$ and trap $(0.6 \%)$.

Most of the fishing gears in this study are illegal due to its mesh size and destructive behavior of fish biodiversity (Table 2). Rahman et al. (2017) found the highest mesh size for gill net $(10 \mathrm{~cm})$ and the lowest size push net $(0.5 \mathrm{~cm})$ in the Agunmukha River, this study was close to our findings. The highest price was observed in case of ber jal due to its demand, supply rate and its catching effort and the lowest price was for wounding gear (Table
2). The highest CPUE was in ber jal depending on its massive dimension and mesh size. On the other hand, the highest fishing effort was in jhaki jal due to its maximum use (Table 2). These values were higher than the findings of Rahman et al. (2017). However, most of the fishermen caught fish species by using jhaki jal, thela jal and current jal to bring their livelihood. Fishermen caught fish throughout the year but comparative higher amount fish was caught during dry season (January to March) which was agreed with Miah et al. (2010). Accordance with DoF (2018), the cost of fishing gears were ranged from 150-1,50,000 Tk and the findings were similar to the present study.

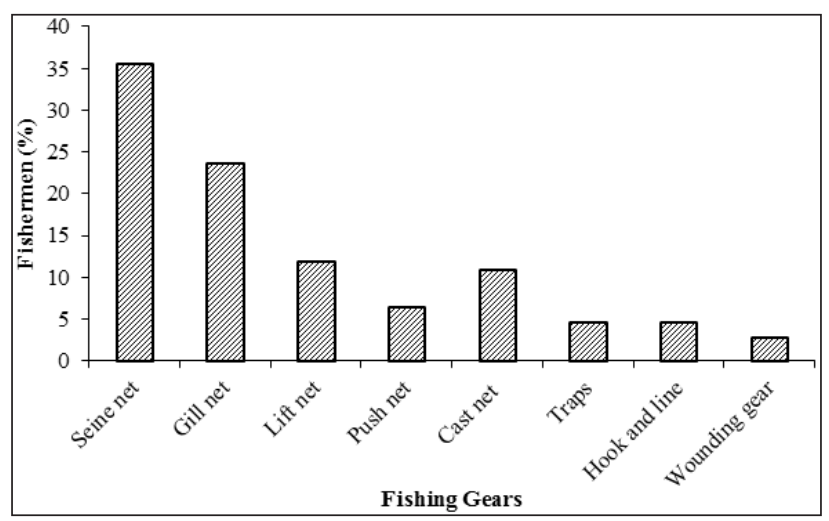

Fig. 5: Fishing gear used by fishermen in the beel

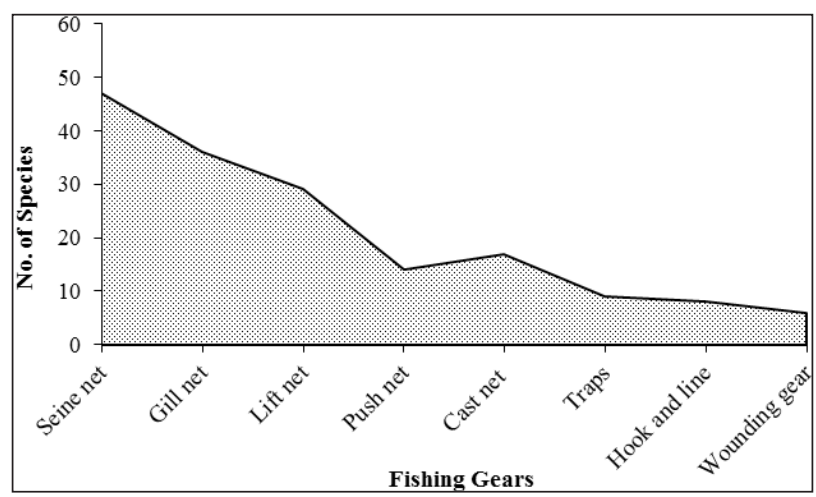

Fig. 6: Number of species caught by fishing gear in the Chinadi beel

Generally fish was caught throughout the year using different fishing gears. It was found that February, March and April are dry season and therefore limited numbers of fishing gear are used here. Mainly lift nets, traps, hooks, and lines were used during the dry season (Table 2). The fish biodiversity is decreasing rapidly day by day. Biodiversity management strategies should be taken to prevent illegal fishing, seizing of destructive fishing gears 
and also protecting potential breeding habitats. Mass awareness must be required to protect the threatened fish species from being extinct from this wetland; also fishermen and by protecting various fish fauna resources. It is recommended to strong implementation of all conservation guidelines and acts to stop illegal catching practices and pollution in the beel.

\section{CONCLUSION}

The present investigation revealed that the fish biodiversity availability and the fishing gears used for fishing in the Chinadi beel. The beel has a rich fish biodiversity and important for fisheries resources in the middle-east part of Bangladesh. None Governmental as well as private survey has not been performed about the estimation of fish fauna biodiversity and fishing gears used for fishing of Chinadi beel. But now-a-days, biodiversity of fish was decreased due to over fishing, water pollution, heavy siltation, rapid urbanization and intervention of human. All these causes have been generated a high impact on ecology and ecosystem of beel. However, the water quality of the beel is also deteriorating day by day resulting in decreasing of availability of fish species and other aquatic biodiversity occur gradually. Extensive research on biodiversity and fishing gears are much crucial to know the variations of biodiversity and livelihood of the fishermen community for their development and sustainable fishery management. For fish species diversity protection of Chinadi Beel the Community Based Fisheries Management system and sustainable fisheries management practices must be acquainted among the fishermen.

\section{ACKNOWLEDGMENTS}

The authors wish to thank Md. Saiful Islam, Assistant Director, BIBIYA Dairy, Agro and Food Ltd., Nikunja-2, Khilkhet, Dhaka-1229, Bangladesh for his valuable support. Authors also thank to the local fishers of the Chinadi beel, Narsingdi district, Bangladesh for helping us to collect data.

\section{REFERENCES}

Ahmed, K.K.U., Hasan, K.R., Ahamed, S.U., Ahmed, T. and Mustafa, G. 2004. Ecology of Shakla heel (Brahmanbaria), Bangladesh. Bangladesh J. Fish. Res., 8(2): 101-111.

Ahmed, N. 1971. Government of East Pakistan directories of fisheries In: Fishing gear of East Pakistan. East Pakistan Fishery Department, East Pakistan.
Ahsan, M.R.U. 2008. A study of fish biodiversity and marketing system in Chalan beel. M.Sc. thesis, Department of Fisheries Management, Bangladesh Agricultural University, Mymensingh, pp. 91.

Alam, M.S., Flowra, F.A., Salam, M.A., Kabir, A.K.M.A. and Ali, H. 2009. Fishing gears, fish marketing and livelihood status of the poor fishermen around the Basantapur beel at Lalpur Upazila. J. Agrofor. Environ., 3(1): 17-20.

Alam, M.S., Hossain, M.S., Monwar, M.M. and Hoque, M.E. 2013. Assessment of fish distribution and biodiversity status in Upper Halda River, Chittagong, Bangladesh. Int. J. Biodivers. Conserv., 5(6): 349-357.

Alam, S.S., Ali, M.Y. and Tsai, C.F. 1997. Fishing gears of floodplain fisheries in Bangladesh: A case study of Chanda, BSKB and Halti beels. Openwater Fisheries of Bangladesh. University Press, Dhaka.

Ali, M.M., Hossain, M.B., Masud, M.A. and Alam, M.A.W. 2015. Fish species availability and fishing gears used in the Ramnabad river, Southern Bangladesh. Asian. J. Agric. Res., 9(1): 12-22.

Ali, M.Y. 1997. Fish, Water, and People: Reflections on Inland Openwater Fisheries Resources of Bangladesh. University Press Limited, Red Crescent Building, 114-Motijheel, Dhaka-1000.

Aosomboon, P. 1994. Small-scale fishing gear used in the artificial reef areas, Ranong Province, Thailand. The Effect of Artificial Reef Installation on the Bio-socioeconomics of Smallscale Fisheries in Ranong Province, Thailand. Bay of Bengal programme for Fisheries Development, Madras, India. Small-scale Fisherfolk Communities in the Bay of Bengal, pp. 53-65.

Chakrabarty R.D., Roy P. and Singh S.B. 1959. A Quantitative study of the plankton and the physicochemical conditions of the river Jumna at Allahabad in 1954-55. Indian J. Fish., 6(1): 186-203.

Chakrabarty, R.D., Roy, P. and Singh S.B. 1959. A Quantitative study of the plankton and the physicochemical conditions of the river Jumna at Allahabad in 1954-55. Indian J. Fish., 6(1): 186-203.

Chakraborty, B.K. and Mirza, M.J.A. 2007. Study of aquatic biodiversity of Gharia beel of Bangladesh. J. Crop Weed, 3(1): 23-34.

Darwall W.R.T. and Vié, J.C. 2005. Identifying important sites for conservation of freshwater biodiversity: extending the species-based approach. Fish. Manag. Ecol., 12(5): 287-293.

Das, T., Das, K., Dutta, N. and Gupta, A. 2003. Status of capture fishery in river Barak, Assam, India. In: The Second International Symposium on the management of large rivers for fisheries, Combodia, pp. 11-14.

Dewan, S. and Mazid, M.A. 1994. Productivity, exploitation and fishing technology of inland open-water fisheries, Bangladesh. Bangladesh Fisheries Research Institute, Mymensingh, Bangladesh.

DoF. 2018. Jatio Motshow Soptaha Sankalon. Department of Fisheries, Ministry of Fisheries and Livestock, Government of the People's Republic of Bangladesh, Ramna, Dhaka, Bangladesh. 
Ehshan, M.A., Hossain, M.S., Razzaque, A. and Alam M.S. 2000. An unusual but important fishery of Chanda beel. Bangladesh J. Zool., 28(1): 69-74.

Flowra, F.A., Islam, M.A., Jahan, S.N., Samad, M.A. and Alam, M.M. 2011. Status and decline causes of fishing activities of the Baral River, Natore, Bangladesh. J. Sci. Found., 9(1-2): 115-124.

Froese, R. and Pauly, D. 2016. FishBase. World Wide Web Electronic Publication.

Galib, S.M., Naser, S.M.A., Mohsin, A.B.M., Chaki, N. and Fahad, M.F.H. 2013. Fish diversity of the River Choto Jamuna, Bangladesh: present status and conservation needs. Int. J. Biodivers. Conserv., 5(6): 389-395.

Galib, S.M., Samad, M.A., Mohsin, A.B.M., Flowra, F.A. and Alam, M.T. 2009. Present status of fishes in the Chalan Beel-the largest beel (wetland) of Bangladesh. Int. J. Animal Fish. Sci., 2(3): 214-218.

Halim, M.A., Salam, M.A. and Hossain, M.S. 2017. Fish biodiversity in Kafrikhal beel under Mithapukur upazila, Rangpur, Bangladesh. Int. J. Fish. Aquat. Stud., 5(2): 487491.

Haroon, A.K.Y., Halder, G.C., Rahman, S.L., Razzaque, M.A., Alam, M. and Amin, S.M.N. 2002. Sylhet-Mymensingh basin fish stock assessment. Bangladesh Fisheries Research Institute, Reverine Station, Chandpur, Bangladesh.

Hemal, S., Uddin, M.S., Uddin, M.S., Majumdar, B.C., Rasul, M.G. and Alam, M.T. 2017. Present status and problems of fish seed marketing in Sylhet district, Bangladesh. Res. Agric. Livest. Fish., 4(1): 45-54.

Hossain, M.A.R., Nahiduzzaman, M., Sayeed, M.A., Azim, M.E., Wahab, M.A. and Olin, P.G. 2009. The Chalan beel in Bangladesh: Habitat and biodiversity degradation, and implications for future management. Lake. Reserv. Res. Manage., 14: 3-19.

Hossain, M.S., Das, N.G., Sarker, S. and Rahaman, M.Z. 2012. Fish diversity and habitat relationship with environmental variables at Meghna river estuary, Bangladesh. Egypt. J. Aquat. Res., 38(3): 213-226.

Hossain, M.Y., Rahman, M.M., Fulanda, B., Jewel, M.A.S., Ahamed, F. and Ohtomi, J. 2012. Length-weight and length-length relationships of five threatened fish species from the Jamuna (Brahmaputra River tributary) River, northern Bangladesh. J. Appl. Ichthyol., 28(2): 275-277.

Imteazzaman, A.M. and Galib, S.M. 2013. Fish fauna of halti beel, Bangladesh. Int. J. Curr. Res., 5(1): 187-190.

IUCN. 2015. Red list of threatened fishes of Bangladesh. IUCN-The World Conservation Union.

IUCN. 2020. Red list of threatened fishes of Bangladesh. IUCN-The World Conservation Union.

Jaman, M.N., Hasan, M.M., Ripon, M.A.S., Debnath, S.K. and Hoque, M.S. 2019. Efficiency of fishing gears used in the Payra river at Dumki upozila in Patuakhali district. Int. J. Oceanogr. Aquacul., 3(1): 000157.

Joadder, M.A.R., Galib, S.M., Haque, S.M.M. and Chaki, N. 2015. Fishes of the river Padma, Bangladesh: Current trend and conservation status. J. Fish., 3(2): 259-266.
Khaled, M. 1985. A manual survey on fishing gear and catch assessment in Bangladesh. Bangladesh J. Aqua., 6-7(1): 31-34.

Kostori, F.A., Parween, S. and Islam, M.N. 2011. Availability of small indigenous species (SIS) of fish in the Chalan Beelthe largest wetland of Bangladesh. Univ. J. Zool., Rajshahi University, 30: 67-72.

Majumdar, B.C. 2017. Comparison of the changes in nutritional quality of three important small indigenous fish species in Bangladesh at room temperature $\left(27-31^{\circ} \mathrm{C}\right)$ : A review. J. Animal Res. Nutrition, 2(2): 15.

Majumdar, B.C. and Rashid, I. 2017. Microbiological properties of dry salted Hilsa, Tenualosa ilisha (Hamilton, 1822) fish of Bangladesh. J. Fish. Life Sci., 2(2): 4-9.

Majumdar, B.C., Shaha, D.C., Rasul, M.G. and Khan, M. 2016. Fish production in floodplain of Bangladesh: A Review. Int. J. Natural Sci., 6(2): 89-95.

Miah, M.I., Ferdausi, R., Hasan, K.R., Siddiq, M.A. and Farid, S.M. 2010. Species composition and gear used in fishing during premonsoon period in the Shitalakshya river at Siddirgonj area, Narayangonj. J. Agrofor. Environ., 4(1): 71-73.

Mohsin, A.B.M. and Haque, E. 2009. Diversity of fishes of Mahananda River at Chapai Nawabgonj district. Res. J. Biol. Sci., 4(7): 828-831.

Mohsin, A.B.M., Hasan, M.M. and Galib, S.M. 2009. Fish diversity of community based fisheries managed oxbow lake (Bookbhara Baor) in Jessore. Bangladesh. J. Sci. Found., 7(1): 121-125.

Mohsin, A.B.M., Yeasmin, F., Galib, S.M., Alam, B. and Haque, S.M.M. 2014. Fish fauna of the Andharmanik River in Patuakhali, Bangladesh. Middle-East J. Sci. Res., 21(5): 802-807.

Rahman, A.K.A. 1998. Women's participation in aquaculture and fisheries for poverty alleviation in Bangladesh: Proshika's experience. $5^{\text {th }}$ Asian fisheries forum for international conference on fisheries and food security beyond the year 2000, Chiang Mai, Thailand, $11^{\text {th }}-14^{\text {th }}$ November.

Rahman, A.K.A. 2005. Freshwater Fishes of Bangladesh (Second ed.). University of Dhaka, Dhaka, Bangladesh.

Rahman, M.B., Hoque, M.S. and Hasan, M.M. 2015. Selectivity of fishing gears and their effects on fisheries diversity of Rabnabad channel of Patuakhali district in Bangladesh. Acad. Res. Int., 6(6): 184-196.

Rahman, M.B., Hoque, M.S., Rahman, M.M. and Nahar, A. 2017. Exploration of fishing gear and fisheries diversity of Agunmukha river at Galachipa upazila in Patuakhali district of Bangladesh. Iran. J. Fish. Sci., 16(1): 108-126.

Rahman, M.M. 2000. Comparison of benthic fauna of two beels of Netrokona district under different management conditions. M.Sc. thesis, Department of Aquaculture, Bangladesh Agricultural University, Mymensingh, pp. 66.

Rahman, M.M., Hossain, M.Y., Ahamed, F., Fatematuzzhura, S.B.R., Abdallah, E.M. and Ohtomi, J. 2012. Biodiversity in the Padma distributary of the Ganges River, Northwestern 
Bangladesh: Recommendations for Conservation. World J. Zool., 7(4): 328-337.

Rahman, M.M., Rahman, M.B., Rithu, M.N.A. and Hoque, M.S. 2016. Observation on selectivity of fishing gears and ichthyofaunal diversity in the Paira river of southern Bangladesh. Int. J. Fish. Aquat. Stud., 4(1): 95-100.

Rahman, S., Chakraborty, B., Razzak, A., Paul, S.K. and Tsai, C. 1993. The study on fishing gear selectivity. Bangladesh Fisheries Research Institute, Shantahar, Bogra.

Saha B.K., Hossain M.A. 2002. Saldu beel fishery of Tangail. Bangladesh J. Zoo., 30(2): 187-194.

Sakawat, H.B. 2002. Haor fisheries resources in Itna Upazila under the district of Kishoregonj and their management practices. M.Sc. thesis, Department of Fisheries Management, Bangladesh Agricultural University, Mymensingh, pp. 88.

Shahjahan, M., Miah, M.I., Haque, M.M. 2001. Present status of fisheries in the Jamuna river. Pak. J. Biol. Sci., 4(9): 1173-1176.

Sheikh, A.H., Mondal, A.R., Majumdar, B.C., Rayhan, A., Hossen, M.N. 2018. Spawning and mortality of eggs and larvae produced by different brood sizes of Walking Catfish (Clarias batrachus L.). J. Appl. Adv. Res., 3(3): 78-83.
Shovon, M.N.H., Majumdar, B.C. and Rahman, Z. 2017. Heavy metals (lead, cadmium and nickel) concentration in different organs of three commonly consumed fishes in Bangladesh. Fish. Aquac. J., 8(3): 207.

Siddiq, M.A., Miah, M.I., Ahmed, Z.F. and Asadujjaman, M. 2013. Present status of fish, fishers and fisheries of Dogger beel in Hajigonj upazila, Chandpur, Bangladesh. J. Aquat. Sci., 1(2): 39-45.

Siddique, M.A. 2001. A study on socio-economic status of fishermen and fish marketing system in Mymensingh district, Bangladesh. M.Sc. thesis, Department of Fisheries Management, Bangladesh Agricultural University, Mymensingh, pp. 73.

Talwar, P.K. and Jhingran, A.G. 1991. Inland Fishes of India and Adjacent Countries (Vol. 12). IBH publishing Co. Pvt. Ltd., New Delhi, India.

Zafar, M.S., Amin, M.N. and Iqbal, M.J. 2007. Biodiversity of fisheries organisms in the Pagla river of Bangladesh. Bangladesh J. Fish., 30: 165-175. 
